\title{
PENTINGNYA ADMINISTRASI KESISWAAN BAGI LEMBAGA PENDIDIKAN
}

\author{
Muhammad Yasir \\ Program Studi Pendidikan IPS Fakultas Keguruan dan Ilmu Pendidikan \\ Universitas Lambung Mangkurat \\ Banjarmasin \\ Email:2010128110002@mhs.ulm.ac.id
}

\begin{abstract}
Abstrak
Administrasi ialah suatu penataan atau pengaturan suatu kegiatan atau aktivitas dalam proses mencapai tujuan. Administrasi merupakan suatu hal yang begitu penting dalam sebuah organisasi atau lembaga. Administrasi berperan penting dalam proses perancanaan, pengaturan dan pengelolaan. Begitu pula dalam lembaga pendidikan, administrasi begitu penting. Administrasi kesiswaaan merupakan salah satu jenis administrasi yang harus ada di dalam lembaga pendidikan. Administrasi kesiswaan berhubungan dengan segala hal yang menyangkut siswa di sekolah. Lalu seberapa pentingkah administrasi kesiswaan tersebut. Pada artikel ini akan dibahas mengenai "Pentingnya Administrasi Kesiswaan bagi Lembaga Pendidikan". Dengan mengetahui dan memahami betapa pentingnya administrasi kesiswaan, diharapkan untuk mempersiapkan pengelola administrasi yang tepat agar pelaksanaan administrasi kesiswaan dapat terlaksana dengan lancar dan sukses.
\end{abstract}

Kata Kunci: Administrasi, siswa, lembaga pendidikan

\section{PENDAHULUAN}

Pendidikan merupakan sesuatu yang begitu penting dalam kehidupan manusia, karena pendidikan memiliki peranan dan fungsi untuk mengembangkan pengetahuan dan keterampilan manusia. Begitu pula tujuan pendidikan ialah untuk menghasilkan generasi penerus bangsa yang berkualitas dan unggul agar dapat bersaing di era perkembangan jaman yang begitu pesat. Berhasilnya suatu pendidikan bisa disebabkan oleh faktor internal dan faktor eksternal. Faktor internal ialah bagaimana pengelolaan manajemen administrasi di lembaga pendidikan tersebut. Sedangkan faktor eksternal nya ialah bagaimana lembaga pendidikan menghadapi lingkungan sekitar dan perkembangan jaman.

Administrasi merupakan suatu kegiatan untuk melayani, mengelola, mengarahkan dan mengatur suatu lembaga, organisasi, ataupun perusahaan. Peranan administrasi begitu penting, karena dapat menentukan keberhasilan suatu tujuan yang ingin dicapai. Administrasi akan berhasil dengan baik apabila didasarkan atas prinsip-prinsip yang ada. Orang yang berperan dalam administrasi ialah orang yang sudah terlatih dalam bidangnya, yang sudah terampil dan sudah mendapatkan ilmu dari pendidikan ataupun pelatihan. Lembaga pendidikan merupakan salah satu tempat yang memerlukan suatu administrasi untuk mensukseskan program-program kerja yang ingin dicapai. 
Administrasi dapat diartikan sebagai suatu proses perencanaan, pengelolaan, pengorganisasian, penggerakan dan pengontrolan sumber daya guna mencapai suatu hal yang dinginkan dapat tercapai secara efektif dan efesien. Proses pendidikan dan pembelajaran pada suatu lembaga pendidikan dipengaruhi oleh beberapa faktor, salah satunya ialah tenaga administrasi sekolah. Administrasi yang ada di lembaga pendidikan disebut administrasi pendidikan. Keberhasilan pendidikan di sekolah harus didampingi dengan pelayanan administrasi sekolah yang sistematis, teratur, terarah dan terencana. Dalam pelaksanaan administrasi pendidikan harus menyesuaikan dengan perkembangan jaman yang semakin berkembang, maju dan bersaing serta semakin modern.

Komponen-komponen yang ada di penyelenggaraan pendidikan sekolah begitu tergantung dengan administrasi pendidikan. Komponen dalam sekolah yang berhubungan dengan administrasi pendidikan diantaranya ialah kesiswaan, pegawai dan guru, kurikulum, serta sarana dan prasarana. Dengan banyaknya komponen yang ada di sekolah, tentunya diperlukan pembagian tugas administrasi disetiap komponen tersebut agar lebih jelas dan terprogram. Administrasi kesiswaan ialah segala sesuatu yang berhubungan dengan siswa/peserta didik. Administrasi kepegawaian dan guru berhubungan dengan tugas dan perannya dalam sekolah. Administrasi kurikulum berhubungan dengan sistem pembelajaran sesuai dengan kurikulum yang ada. Dan administrasi sarana dan prasarana berhubungan dengan fasilitas yang ada di sekolah tersebut. Semua komponen tersebut begitu penting untuk mensukseskan tujuan sekolah yang ingin dicapai. Administrasi pendidikan, termasuk administrasi kesiswaan memiliki tujuan atau misi yang terdapat didalamnya misi kemanusiaan yang tinggi nilainya. Misi tersebut ialah untuk manusia menjalankan dan melakukan proses kerjasama yang disebut pendidikan, sehingga berhasil atau tidaknya suatu lembaga pendidikan adalah bagaimana pengelolaan administrasi pada sekolah tersebut.

\section{METODE}

Metode yang digunakan pada penulisan artikel ini ialah pendekatan deskriptif kualitatif yang digunakan dalam metode kepustakaan atau studi literatur yaitu dengan cara mencari, menelaah dan memahami data-data seperti isi artikel, buku-buku, dokumen, atau jurnal-jurnal ilmiah lainnya yang relevan dan mendukung untuk menggambarkan atau menjelaskan mengenai seberapa pentingnya administrasi dalam lembaga pendidikan khususnya administrasi kesiswaan bagi lembaga pendidikan dan kesuksesan pelaksanaannya. Sumber data yang digunakan pada penulisan ini didapatkan dari sumber ilmiah yang ada pada google scholer atau google cendikia. 


\section{PEMBAHASAN}

Administrasi merupakan suatu proses yang dilaksanakan guna menjalankan usaha dengan baik yang memerlukan pemikiran, perencanaan, pengaturan, serta pengarahan untuk memanfaatkan atau mengikutsertakan segala potensi yang ada baik itu individu maupun kelompok secara efektif dan efisien, demi mencapai tujuan bersama. Siswa atau peserta didik merupakan seseorang yang menempuh pendidikan semasa hidup ataupun disekolah. Dan mendapatkan pelayanan dari lembaga pendidikan untuk mengembangkan potensinya baik bakat, minat, pengetahun dan keterampilan melalui proses belajar pada jalur, jenjang atau jenis pendidikan yang tak hanya satu. Agar dia tumbuh dan berkembang serta mempunyai masa depan yang cerah.

Administrasi kesiswaan atau peserta didik merupakan bagian dari administrasi sekolah. Administrasi kesiswaan adalah segala kegiatan atau aktivitas administrasi yang berhubungan dengan para siswa/peserta didik. Administrasi kesiswaan ialah bentuk usaha pengaturan atau penataan peserta didik dari awal masuk sekolah sampai mereka lulus/selesai dari sekolah tersebut. Administrasi kesiswaan merupakan suatu kegiatan yang diusahakan dan direncanakan sebaik mungkin dan disengaja, dan dilakukan secara berkelanjutan terhadap semua peserta didik yang ada disekolah supaya proses belajar mengajar lebih efektif dan efisien. Sebab setiap tahun atau pergantian semester pastinya ada hal-hal mengenai peserta didik yang berubah. Sehingga tujuan dari pendidikan harus ditetapkan agar tercapai sesuai keinginan.

Administrasi kesiswaan merupakan semua proses kerjasama dalam bidang kesiswaan, kerjasama dalam administrasi kesiswaan ialah menyelesaikan permasalahan yang berhubungan dengan peserta didik. Yang dimulai dari penerimaan, pembelajaran sampai dengan kelulusan peserta didik sesuai dengan tujuan yang ingin dicapai secara efektif dan efisien pada suatu sekolah atau lembaga pendidikan lainnya. Administrasi kesiswaan menurut B. Suryosubroto menunjukan pada pekerjaan atau kegiatan pencatatan siswa baru yang dimulai dari penerimaan sampai dengan siswa meninggalkan sekolah tersebut karena sudah tamat mengikuti pendidikan dan dinyatakan lulus. Akan tetapi tidak semua hal mengenai siswa di tanggung jawabi oleh administrasi kesiswaan.

Tujuan dari administrasi kesiswaan adalah untuk mengatur dan mengelola berbagai aktivitas dan kegiatan peserta didik supaya kegiatan proses pembelajaran di sekolah atau lembaga pendidikan dapat berjalan dengan tertib, lancar, teratur serta tercapainya suatu tujuan dari pendidikan. Dengan merencanakan seluruh proses kegiatan untuk pembinaan peserta didik supaya tumbuh dan berkembang dengan baik, dengan cara melayani, membantu, menunjang, atau memenuhi kebutuhan peserta didik. 
Ruang lingkup administrasi kesiswaan mencakup hal-hal yang begitu luas yang bergubungan dengan siswa atau peserta didik dari pendaftaran sampai kelulusan dari lembaga pendidikan atau sekolah. Mustanir berpendapat bahwa cakupan administrasi kesiswaan meliputi kegiatan penerimaan siswa baru atau PPDB (Penerimaan Peserta Didik Baru). Ketatausahan siswa, Pencatatan pembimbingan dan penyuluhan, serta pencatatan prestasi belajar siswa dan pengelolaan kelas. Kegiatan-kegiatan tersebut dilaksanakan dengan perencanaan yang matang dan ditangani oleh tenaga ahli dibidangnya. Agar hal-hal yang menjadi tujuan dapat tercapai dengan lancar dan sukses.

Kegiatan penerimaan siswa baru ialah kegiatan yang tak mudah dilakukan, sebab banyak hal-hal yang perlu disiapkan. Persiapan perlu disiapkan dari jauh-jauh hari sebelum dilaksanakannya penerimaan siswa baru. Diantaranya ialah menentukan jumlah siswa yang akan diterima sesuai kapasitas yang ada, menuntukan syarat-syarat yang harus dipenuhi untuk penerimaan, mempersiapkan konsep tes berupa wawancara maupun soal-soal tertulis, melakukan penyeleksian setelah dilaksanakannya tes dan didasarkan oleh tes tersbut, mempersiapkan pendaftaran ulang bagi peserta didik yang dinyatakan lulus penerimaan, dan membuat laporan kegiatan dan laporan pertanggung jawaban terhadap kepala sekolah.

Kegiatan ketatausahaan siswa menyangkut mengenai hal-hal pendataan yang mana merupakan kelanjutan dari kegiatan penerimaan siswa baru. Setelah dinyatakan lolos dari tahap penerimaan, tentunya harus dilakukan pencatatan di sekolah tersebut agar data-data dari siswa baru terkumpul dan tersimpan dengan rapi. Pencatatan pada umumnya terbagi menjadi dua yaitu dalam buku induk dan buku pelengkap. Buku induk menyangkut identitas siswa yang nantinya akan dibukukan secara lengkap untuk pembagian kelas, jurusan, dan lain-lain. Yang termasuk kedalam sana diantaranya ialah nama, nomor urut pendaftaran, nomor induk sekolah, jenis kelaminnya, nama dan alamat orang tua, pekerjaan orang tua, asal sekolah dan lainnya. Dan ada juga buku pelengkap dari buku induk yang berisi peraturan atau tata tertib yang ada disekolah tersebut yang harus ditaati dan dijalankan serta tidak melakukan hal-hal yang dilarang.

Kegiatan pencatatan penyuluhan atau bimbingan merupakan hal yang diberikan oleh pihak sekolah kepada peserta didik. Agar siswa selama mengikuti proses kegiatan belajar dan kegiatan lainnya disekolah seperti ekstrakurikuler, tidak merasa dirugikan dan berfungsi untuk mencapai suatu hal yang maksimal oleh peserta didik di sekolah tersebut. Penyuluhan atau pembimbingan meliputi dua hal yang ingin dicapai yaitu bimbingan belajar, yang dilakukan pada saat proses pembelajaran dan bimbingan pribadi yang berkaitan dengan keadaan siswa jika mengalami permasalahan disekolah. 
Dan kegiatan pencatatan prestasi belajar siswa atau peserta didik terdiri dari buku-buku yang berfungsi sebagai mana ketentuannya. Buku daftar nilai berisi mengenai rekapan nilai mentah atau langsung dari guru untuk siswa dalam waktu persemester yang rutin dicatat. Buku legger berisi mengenai nilai-nilai dari berbagai macam mata pelajaran dalam satu semester. Buku raport berisi laporan hasil belajar peserta didik di sekolah dalam jangka waktu per semester guna memberitahu prestasi belajar dari siswa kepada dirinya, orang tua, maupun masyarakat. Dan ada buku mutasi yang berisi catatan proses perpindahan sekolah baik masuk ataupun keluar sekolah yang berguna sebagai bukti bahwa siswa tersebut pernah bersekolah disana dan pindahan dari mana ia berasal.

Serta administrasi kesiswaan juga melaksanakan kegiatan yang dilakukan dikelas atau biasa disebut pengelolaan kelas. Pengelolaan kelas bertujuan untuk menciptakan suatu ruang kelas yang kondusif dan nyaman untuk kegiatan pembelajaran. Termasuk didalamnya yaitu interaksi antara guru dan siswa berjalan dengan baik, saat pembelajaran perhatian siswa tertuju pada pemamparan materi, memperhatikan prestasi siswa/peserta didik. Dan perlunya tata tertib dalam kelas untuk menunjang proses pembelajaran, menyesuaikan jadwal pembelajaran, membentuk struktur organisasi kelas serta melengkapi fasilitas dalam kelas untuk proses pembelajaran yang nyaman.

Dengan begitu administrasi kesiswaan merupakan suatu komponen yang begitu penting dan diperlukan dalam sekolah dan lembaga pendidikan. Bahkan kalau tidak ada administrsi kesiswaan kegiatan belajar mengajar tidak akan berjalan dengan baik. Administrasi sangat penting untuk lembaga pendidikan. Berbagai hal yang penting dalam pendidikan dilaksanakan oleh administrasi kesiswaan. Diantaranya melakukan pencatatan mengenai penerimaan siswa baru, mengetahui jumlah dan prestasi yang dimiliki oleh siswa melalui proses pengamatan dalam pembelajaran mengenai pertumbuhan dan perkembangan siswa secara individu dan kelompok. Yang dilakukan dengan cara menghimpun data siswa, dicatat pada buku-buku, dan juga dipelihara dengan cermat tepat dan teratur.

Administrasi kesiswaan berperan penting untuk meningkatkan pengetahuan, kemampuan dan keterampilan serta sikap dari peserta didik untuk kehidupan yang sebenarnya. Menyalurkan dan mengembangkan minat dan bakat peserta didik melalui berbagai aktivitas disekolah. Serta menyalurkan aspirasi, harapan dan untuk memenuhi kebutuhan peserta didik dalam proses pembelajaran. Dengan terpenuhinya berbagai hal tersebut diharapkan peserta didik dapat menjalani kehidupan dengan kebahagian dan kesejahteraan hidup yang berkelanjutan dalam belajar dan menjapai impian-impian peserta didik. Sekolah merupakan 
tempat untuk mengembangkan diri sebaik mungkin, baik dari segi individu, segi sosial, dan potensi lainnya.

\section{SIMPULAN}

Administrasi suatu proses yang dilaksanakan untuk menjalankan usaha dengan baik yang memerlukan pemikiran, perencanaan, pengaturan, serta pengarahan untuk memanfaatkan atau mengikutsertakan segala potensi yang ada baik individu maupun kelompok secara efektif dan efisien, demi mencapai tujuan bersama. Siswa atau peserta didik merupakan seseorang yang menempuh pendidikan semasa hidup ataupun disekolah. Administrasi kesiswaan atau peserta didik merupakan bagian dari administrasi sekolah. Administrasi kesiswaan adalah segala kegiatan atau aktivitas administrasi yang berhubungan dengan para siswa/peserta didik. Administrasi kesiswaan merupakan semua proses kerjasama dalam bidang kesiswaan, kerjasama dalam administrasi kesiswaan menemukan penyelesaian permasalahan yang berhubungan dengan peserta didik.

Tujuan dari administrasi kesiswaan adalah untuk mengatur dan mengelola berbagai aktivitas dan kegiatan peserta didik agar kegiatan pembelajaran di sekolah atau lembaga pendidikan dapat berjalan dengan tertib, teratur, serta tercapainya suatu tujuan dari pendidikan. Ruang lingkup administrasi kesiswaan mencakup hal-hal yang begitu luas dengan siswa atau peserta didik dari pendaftaran sampai kelulusan dari lembaga pendidikan atau sekolah. Kegiatan-kegiatan tersebut dilaksanakan dengan perencanaan yang matang dan ditangani oleh tenaga ahli dibidangnya. Kegiatan penerimaan siswa baru adalah kegiatan yang tidak mudah dilakukan, karena banyak hal-hal yang perlu disiapkan. Administrasi kesiswaan berperan penting untuk meningkatkan pengetahuan, kemampuan dan keterampilan serta sikap dari peserta didik untuk kehidupan yang sebenarnya. Menyalurkan dan mengembangkan minat dan bakat peserta didik melalui berbagai aktivitas disekolah. Serta menyalurkan aspirasi, harapan dan untuk memenuhi kebutuhan peserta didik dalam proses pembelajaran 


\section{DAFTAR PUSTAKA}

Abbas, E. W. (2020). Menulis Artikel Jurnal. Menulis Artikel Jurnal.

Abbas, E. W. (2020). Menulis Artikel Jurnal Internasional.

Abbas, E. W. (2020). Menulis di Otak dan Menuliskan Tulisan di Otak.

Amka, A. (2021). Manajemen dan Administrasi Sekolah.

Azis, R. (2016). Pengantar administrasi pendidikan.

Fajrin, M. F., Rifqi, N., \& Arsyam, M. (2021). ADMINISTRASI KESISWAAN DALAM PENDIDIKAN.

Febriyanti, F. (2019). Implementasi Administrasi Kesiswaan di MTs Negeri 1 Kota Cilegon (Doctoral dissertation, UIN SMH BANTEN).

Hasjun, D. A. (2017). Efektivitas Layanan Administrasi Kesiswaan dalam Meningkatkan Mutu Manajemen Berbasis Sekolah di SD InpresTimbuseng Kecamatan Pattallassang Kabupaten Gowa (Doctoral dissertation, Universitas Islam Negeri Alauddin Makassar).

Idris, J. (2014). MANAJEMEN KESISWAAN PADA MADRASAH TSANAWIYAH NEGERI COT GUE KABUPATEN ACEH BESAR. Jurnal Administrasi Pendidikan: Program Pascasarjana Unsyiah, 2(1).

MUSTANIR, M., Rusmini, R., \& Bawaihi, B. (2021). MANAJEMEN PELAYANAN ADMINISTRASI KESISWAAN DI SEKOLAH MENENGAH ATAS NEGERI 10 KOTA $J A M B I$ (Doctoral dissertation, UIN Sulthan Thaha Saifuddin Jambi).

Ngalim Purwanto, M. 2010. Administrasi dan Supervisi Pendidikan. Bandung: PT Remaja Rosdakarya.

Nurmah, Y. (2015). PELAKSANAAN ADMINISTRASI KESISWAAN DI SMPN 10 BANJARBARU.

Uhansyah, U. (2017). Pentingnya administrasi sekolah untuk kemajuan pendidikan. ITTIHAD, 15(27). 